\title{
AN EXAMINATION ON THE USE OF IMMERSIVE REALITY TECHNOLOGIES IN THE TRAVEL AND TOURISM INDUSTRY
}

Fatih ERCAN 1

\author{
ABSTRACT \\ Keywords: \\ Immersive Reality \\ Technology \\ Travel and Tourism
}

JEL Codes:

M30, M31

\author{
Received Date (Başvuru Tarihi): \\ Accepted Date (Kabul Tarihi): \\ Published Date (Yayın Tarihi):
}

$18 / 05 / 2020$

$18 / 06 / 2020$

$25 / 06 / 2020$

Recent developments in technology have changed the way people communicate and interact. In addition, the relationship between the business and the customer is carried to a different dimension. IR (immersive reality) is the name given to new reality technologies including $V R$ (virtual reality), $A R$ (augmented reality) and $M R$ (mixed reality) technologies, which are becoming more and more common in use today. It is seen that the use of these technologies in fields such as medicine, engineering, production, service and marketing have become important today. The purpose of this study is to reveal the use of the IR technologies in the travel and tourism industry and current applications in detail. The data obtained by using document analysis technique were compiled for the purpose of the study. As a result of the study, it has been determined that the IR technologies are used by hotel businesses, restaurants, travel companies, museums and historical sites for purposes such as customer relations, reservation, product and service provision, promotion and marketing.

\section{SEYAHAT VE TURIZM ENDÜSTRISINIDE SARMALAYAN GERÇEKLİK TEKNOLOJILERININ KULLANIMININ İNCELENMESİ}

$\ddot{O Z Z}$

Anahtar Kelimeler:

Sarmalayan Gerçeklik

Teknoloji

Seyahat ve Turizm

JEL Kodlar:

M30, M31
Son yullarda teknolojide meydana gelen gelişmeler kişilerin iletişim ve etkileşim kurma şeklini değiş̧tirmektedir. Bununla birlikte, işletme-müşteri arasındaki ilişkiler de farklı bir boyuta taşınmaktadır. Sarmalayan gerçeklik, günümüzde kullanımı giderek yaygınlaşan sanal gerçeklik, artırılmış gerçeklik ve karma gerçeklik teknolojilerini kapsayan yeni gerçeklik teknolojilerine verilen isimdir. Tip, mühendislik, üretim, hizmet, pazarlama gibi alanlarda bu teknolojilerin kullanımının günümüzde önem kazanmaya başladığ görülmektedir. Bu çalş̧manın amacl, seyahat ve turizm endüstrisinde sarmalayan gerçeklik teknolojileri kullanımının ve mevcut uygulamaların detaylı bir şekilde incelenerek ortaya konmasıdır. Doküman analizi tekniği ile elde edilen veriler çalışma amacı doğrultusunda derlenmiştir. Çalışma sonucunda, sarmalayan gerçeklik teknolojilerinin müşteri ilişkileri, rezervasyon, ürün ve hizmet sunumu, tanıtım, pazarlama gibi amaçlarla otel işletmeleri, restoranlar, seyahat işletmeleri, müzeler ve ören yerleri tarafindan kullanıldığı tespit edilmiştir.

\footnotetext{
1 Dr. Öğr. Üyesi, Zonguldak Bülent Ecevit Üniversitesi, Karadeniz Ereğli Turizm Fakültesi, fatih.ercan@beun.edu.tr, $\underline{\text { https://orcid.org/0000-0001-6469-3000 }}$
} 


\section{INTRODUCTION}

The developments in technology in the 21st century that we are in have a wide range of effects from the daily life of individuals to the activities of businesses. The widespread use of technology causes innovations in product and service offerings and different experiences are created for consumers. These technologies, which increase the interaction between the physical reality and the virtual world, are the technologies that change the world today. Immersive reality (IR) technologies, which have emerged in recent years and continue to develop rapidly, are new technological tools that have the opportunity to apply in a wide range from production to service industry. Beyond the use of technology, the IR that allows people to interact in a virtual environment is shown among the technologies that are becoming widespread in the travel and tourism industry today (Hammady et al., 2020: 3465; Nayyar et al., 2018: 156).

IR which is a roof concept that covers all of virtual reality (VR), augmented reality (AR) and mixed reality (MR) technologies (Handa, Aul and Bajaj, 2012: 1), it refers to technologies that have a wide range of uses in the travel and tourism industry today. Hospitality businesses, which have an important place in tourism, adapt these technologies to service delivery, experience differentiation, marketing and promotion activities. Similarly, food and beverage businesses are trying to utilize the IR technologies that surround their product and service offerings. However, when other studies in the related literature are examined (Ramos et al., 2018; Gaberli, 2019), museums and ruins can be shown as examples of other touristic units that are trying to serve using the IR technologies. While visitors are visiting destinations, they can use IR technologies as a tour guide for information and get help from interactive VR and AR tools. IR technologies increase the interaction between the real and virtual world, make virtual objects more concrete, thus enabling the creation of new customer experiences (Flavian, Ibanez-Sanchez and Orus, 2019: 547; Fritz, Susperregui and Linaza, 2005: 1). In addition, IR technologies are important technologies that increase business performance in businesses and increase demand along with service innovations (Volkow and Howland, 2018: 29). These technologies also increase accessibility to destinations and tourism businesses, making touristic products more accessible to everyone (Mosieeva et al., 2019: 5313). 
The use of IR technologies for businesses and customers in the travel and tourism industry can help to create better service delivery and customer experience. In this study, it is aimed to examine the purposes and areas of use of IR technologies in detail in the travel and tourism industry. In line with this main purpose, firstly, the structure of IR technology and the characteristics of technology-supported travel experiences were examined within the scope of reality-virtuality understanding. Afterwards, general information about VR, AR and MR concepts are given and their usage areas, importance and benefits in travel and tourism industry are emphasized. It is anticipated that examining the place and functions of these new technologies in the travel and tourism industry will be beneficial in understanding the concept of the IR and the widespread use of it in the industry. It can be thought that the in-depth study of the subject in terms of the travel and tourism industry will contribute significantly to the development of theoretical knowledge in the relevant academic literature in the national and international arena.

\section{FROM PHYSICAL REALITY TO DIGITAL REALITY: REALITY- VIRTUALITY}

People's thoughts about reality, the dimensions of reality and perceptions about reality are the topics that have been discussed for centuries. The doubts and assumptions about the real and the unreal have always been discussed throughout history. In the dictionary of the Turkish Language Association (TDK), reality is defined as "all that is real, what exists, truth, reality" and virtual is "hypothetically designed and mentally imagined." Therefore, while the reality of something is related to its existence, virtuality means that things that do not actually exist are designed in the mind (Orhan and Karaman, 2011: 374). Over time, it is known that the concepts of reality and virtuality get very close to each other in terms of meaning, these concepts are mixed and discussed over them. Digital reality is described as an innovation that develops day by day, draws the attention of people, and is used in fields such as entertainment, education and culture (Ferhat, 2016: 724-725).

It is seen that the internet, which has entered the human life towards the end of the 20th century and whose usage rate has increased gradually, has become an 
important communication and interaction tool for everyone with the rapid developments in technology today. Internet technologies, which are used in many areas from individuals' daily life to business life, are adopted by a wide audience due to the convenience and advantages they offer. Thanks to the technology, communication opportunities in written, visual and voice increase, it is possible to access information and conduct in-depth research. Especially, in recent years, mobile smart technologies are increasing the connection and interaction with the digital world to a higher level. In other words, the relationship between the physical world and the virtual world changes day by day and is carried to more advanced levels. People support their experiences with digital technologies and share them with other people. It is therefore possible to qualify technology as an important tool that creates new experiences for people.

Virtual environments are digital platforms where users are completely surrounded by an artificial world. This environment may or may not reflect the characteristics of the physical environment in the real world. The virtual environment can be in the form of real or fiction and it transcends the physical world by creating a world that rules time and spatial features. However, the real world is completely limited by the laws of physics. Instead of evaluating these two concepts as completely opposed to each other, it would be more appropriate to see them as a continuity cycle, which can be described as reality-virtuality continuum. Figure 1 shows the area and elements of mixed reality in reality-virtuality continuum and physical reality is supported by combining real objects with virtual objects (Milgram et al., 1994: 283).

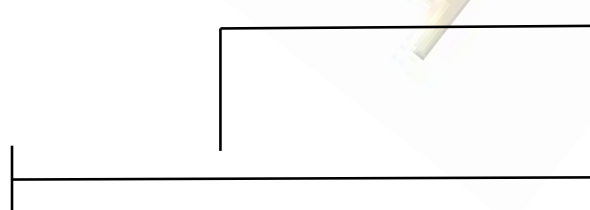

Real Environment $\longrightarrow$ AR
MR

Augmented Virtuality
Virtual Environment

\section{Reality-Virtuality Continuum}

Figure 1. Reality-Virtuality Continuum

Source: Milgram et al., 1994: 283. 
The face-to-face communication between people in the past years occurs in different ways in the digital world today. Virtual chat tools and interactive communication environments change the way of communication, increase the density and eliminate the physical distance barrier. However, the vast possibilities offered by the digital world allow people to see and interact with environments that cannot be physically accessible for various reasons. Flavian, Ibanez-Sanchez and Orus (2019:550) state that developing technologies change the human-technology interaction and that the modern devices with the latest technology can be integrated into the human body as well as the portability. According to the authors, the use of these wearable technologies stimulates and improves the perceptions and senses of the people. It also acts as an intermediary in interpreting, perceiving and interacting with what it sees. Therefore, the embodiment function of virtual technologies emerges here. Activities and objects in the real physical environment are integrated into the virtual world and embodied for humans.

\subsection{New Technological Trend: The Immersive Reality (IR)}

The concept of reality refers to everything that is considered real. Virtuality, on the other hand, shows abstraction and unreality. The possibilities offered by the developing technology today cause the actual elements to be symbolized in the virtual world, and as a result, the perception of reality and virtuality get closer to each other. Through interactive tools and new technologies, such as VR applications, users are provided with virtual experiences, and developments in this area expand the virtual reality application areas. In this way, the lines and boundaries of the concepts of reality and virtuality intersect with each passing day. The use of VR together with AR applications causes the emergence of blended reality, in other words, MR technology (Orhan and Karaman, 2011: 373-375). When the related literature is examined (Bekele et al., 2018; Innovate UK, 2019; Ramos et al., 2018), it is seen that the term "immersive reality" is used as a concept that expresses the use of VR, AR and MR. For this reason, IR will be used in this study as a general concept that covers all three types of reality.

Bekele et al. (2018: 3-4) state that there is no valid term generally accepted by everyone for VR, AR, MR, and they use the IR as a term that covers them all. The 
authors note that these technologies basically combine the real world and the virtual world in different ways, and state that technological tools such as three-dimensional glasses and mobile phones are the tools used in the IR technologies. The authors explain the differences between the IR types as follows:

- AR: aims at enhancing our perception and understanding of the real world by superimposing virtual information on our view of the real world.

- VR: aims at enhancing our presence and interaction with a computer-generated environment without a means to interact with or see the real world.

- MR: aims at blending real and virtual environments.

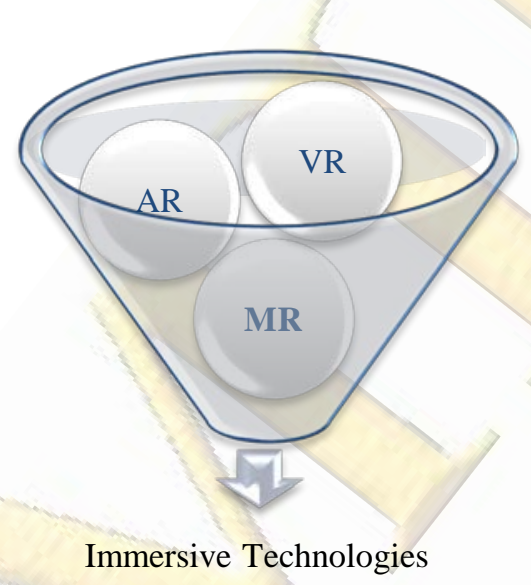

Figure 2. IR Technologies

Source: Created by author.

Immersive technologies such as VR, AR and MR transform people's ways of accessing and interacting with digital information. These technologies have many applications such as collaborative design, experiencing live events, training simulations, retail solutions. However, businesses, university researchers and other practitioners operating in various fields develop and use IR to create economic, social and cultural values. It is possible to summarize these values created with IR under the following titles (Innovate UK, 2019):

a) Product: the ability to develop new and more attractive products and to increase the visibility of the company as an innovator,

b) Market: the ability to expand the markets the company targets and work with a wider set of collaborators,

c) Process: improvements in organisation and efficiency, 
d) Culture: changing the culture of the organization.

\subsection{Technology Supported Experiences in Travel and Tourism Industry}

Travel and tourism is an important industry that contributes to economic, social and cultural development worldwide and stands out with its constantly changing dynamic structure. The developments in communication and transportation technologies cause the travel and tourism movements to increase globally and turn into a large field of activity in which many people participate. Countries that want to get more share from the rising demand in the travel and tourism industry and consequently increasing economic income are trying to offer new experiences for visitors through product differentiation. Creativity can offer a significant advantage in creating these new experiences. Putro (2015: 1-2) states that tourism and creativity are inseparable concepts and it is an industry that requires constant creativity due to the nature of tourism. In addition, the author emphasizes that in the modern information age we are in, creativity in tourism has developed with the developments in technology. New technologies allow innovations in service delivery in the travel and tourism industry and thus new customer experiences.

Technological developments, which are shown as the most important reason for the developments in the tourism industry, play a critical role in diversifying the tourist products and increasing their attractiveness. The opportunities offered by technology increase the attractiveness with new experiences and the tourist services offered are preferred more by the potential visitors. The latest technologies that enable these developments today are IR such as VR, AR and MR. These technologies create three-dimensional visual objects and virtual environments in tourism, enabling tourists to experience tourism businesses, destinations, museums, historical and cultural areas in advance in this virtual environment. In addition, the information function of these technologies can guide tourists during visiting a place (Demirezen, 2019: 2). Therefore, these technologies play an informative, guiding and experience providing role for visitors throughout the process from the beginning to the end of the holiday experience. 
Travel and tourism businesses are now using IR technologies to create new inexpensive and user-friendly service platforms. Applications such as supporting travels with VR experiences or improving the destination experience with AR technology are among the IR technologies that can be shown as examples. In many areas in the travel and tourism industry, the IR is shown as the technology of the future. The immersive tours allow visitors to discover and examine accommodation and touristic attractions as if they were really there. Virtual tours allow visitors to spend more time and communicate more on tourism businesses websites. Therefore, IR technologies are an important tool in the information acquisition before visiting a destination and in the experiences during the visit. IR technologies are available in various touristic services that visitors purchase such as hotels, food and beverage, transportation and tours, combining these services with new experiences (Collins, 2019).

With the development of various mobile and smart technologies, the use of IR technologies is gaining importance in realizing the travels of people and participating in tourism activities. IR technologies allow potential visitors in a different country to visit a destination in a virtual environment and to discover and see the accommodation establishments' rooms (Joseph, 2019). The sense of reality created in the virtual environment, the abstraction of the services offered in the tourism industry and the lack of opportunity to try before can help turn the disadvantages in favor of the consumers. In this sense, IR technologies are an important experience provider and support element. It differentiates tourist experiences and allows new experiences to be created.

\section{VR TECHNOLOGY IN TRAVEL AND TOURISM INDUSTRY}

VR stands out as a new technology that has been used in the travel and tourism industry in recent years. With this technology, the feeling of experiencing real objects is created in the virtual environment with the help of sound, image and motion. In addition to being an effective factor in making people decide to visit destinations, the experiences created by VR cognitively and sensually increase the trend to visit (Kim, Lee and Jung, 2018: 1). In this respect, the use of VR is becoming more and more 
important in the travel and tourism industry, from accommodation to travel information research.

\subsection{VR Concept}

There are many definitions in the literature on VR. In its most basic definition, VR is three-dimensional outputs that appear with high resolution graphics in computer environment. In addition to this technical definition, a definition that highlights the interaction feature can also be made. Accordingly, VR is a threedimensional, interactive virtual world that allows users to interact in real time in a computer environment. In other words, VR is interactions taking place in the virtual world (Putro, 2015: 2-3). Bayraktar and Kaleli (2007: 1) define VR as a threedimensional simulation model that gives participants a sense of reality and allows for mutual communication with a dynamic environment created by computers.

The fact that people interact directly with the environment in the computeraided virtual environment and feel as if they are in this environment are seen as the main points emphasized in the VR definitions (Y1ldırım, Elban, and Y1ldırım, 2018: 63). Beyond the visibility of being in a different place or time, VR refers to all of the virtual objects that contain the digital symbols of certain events, objects, showing objects from the physical world or anything that can only be described in a computer environment (Greengard, 2019: 6). The ultimate VR is realized when the user is fully immersed in the virtual world with special VR headset and controllers to interact and get the information (Ramos et al.., 2018: 3). In VR technology, it is aimed to increase our presence and interaction in the virtual environment in order to see the real world and interact (Bekele et al., 2018: 3).

In the VR experience, users are fully integrated into the digital environment through simulation. In VR, people wear a virtual reality headset. In this case, users get a 360-degree view of an artificial world that tricks their brains, like being in a world where they believe they're walking on the moon or swimming under the ocean. Although the games and entertainment industry are the first to apply this technology, it is emphasized that VR applications can be used in health, education, engineering, construction, military and many other fields (Güzel, 2019). When other studies in the 
related field are examined (Gaberli, 2019; Ramos et al., 2018; Hammady et al., 2020), it is revealed that VR technology can be used in various fields in the travel and tourism industry.

\subsection{VR Use in Travel and Tourism Industry}

It is seen that the conceptualization of tourist experiences was one of the main research topics in the 1960s. The definitions made in these periods emphasize that tourist experiences are different from those in daily life. In academic researches carried out during the period up to the 1990s, it is seen that this definition has changed and that tourism experiences are not much different from routine experiences of daily life. The daily experiences, which are described as the "the end of tourism", are considered as closely related to the touristic experiences that can be experienced with various technological tools. Technologies such as VR and AR are changing the nature, structure and characteristics of tourism experiences today (Gaberli, 2019: 62).

Virtual reality is interactive pictures or videos that enable users to view an entire image at a 360-degree angle. Unlike the regular video image, which is a snapshot from a fixed point, virtual reality captures every frame of a location, an image of the environment. These features can be used in many areas in the travel and tourism industry. For example, by taking 360-degree images of tourism destinations, virtual reality can be used in advertising, promotional catalogs, brochures, websites, social media. It is possible to do this using special cameras, equipment and software. Content created using various equipment can be viewed with the help of VR headset, standard computers or mobile devices. The fact that VR contents can be viewed not only with special headsets but also from computers or mobile devices makes virtual reality more common (ImmersionVR, 2020). Experiences created with virtual reality applications are used in the travel and tourism industry for various purposes such as virtual environmental trips, virtual hotel tours, reservations.

\subsubsection{Virtual Hotel Tours}

It is seen that VR, which is predicted to become the most widely used technology in the near future, has started to become widespread in the tourism sector today. Tourists have started to receive 360-degree virtual guidance support from a 
selection of destinations to directions, from attractions to see and places to eat. This technology, which has recently brought a 360-degree VR dimension to the customer experience in many fields, is rapidly adopted by the hotel businesses in the tourism industry in order to create customer satisfaction. Using VR technology, it is possible to see the hotel to be accommodated in advance, to examine the interior and exterior of the hotel in detail with a virtual tour and to make a purchase decision (Yaral Mercan, 2018). Therefore, VR technology functions as an effective tool that provides detailed promotion opportunities for hotel businesses.

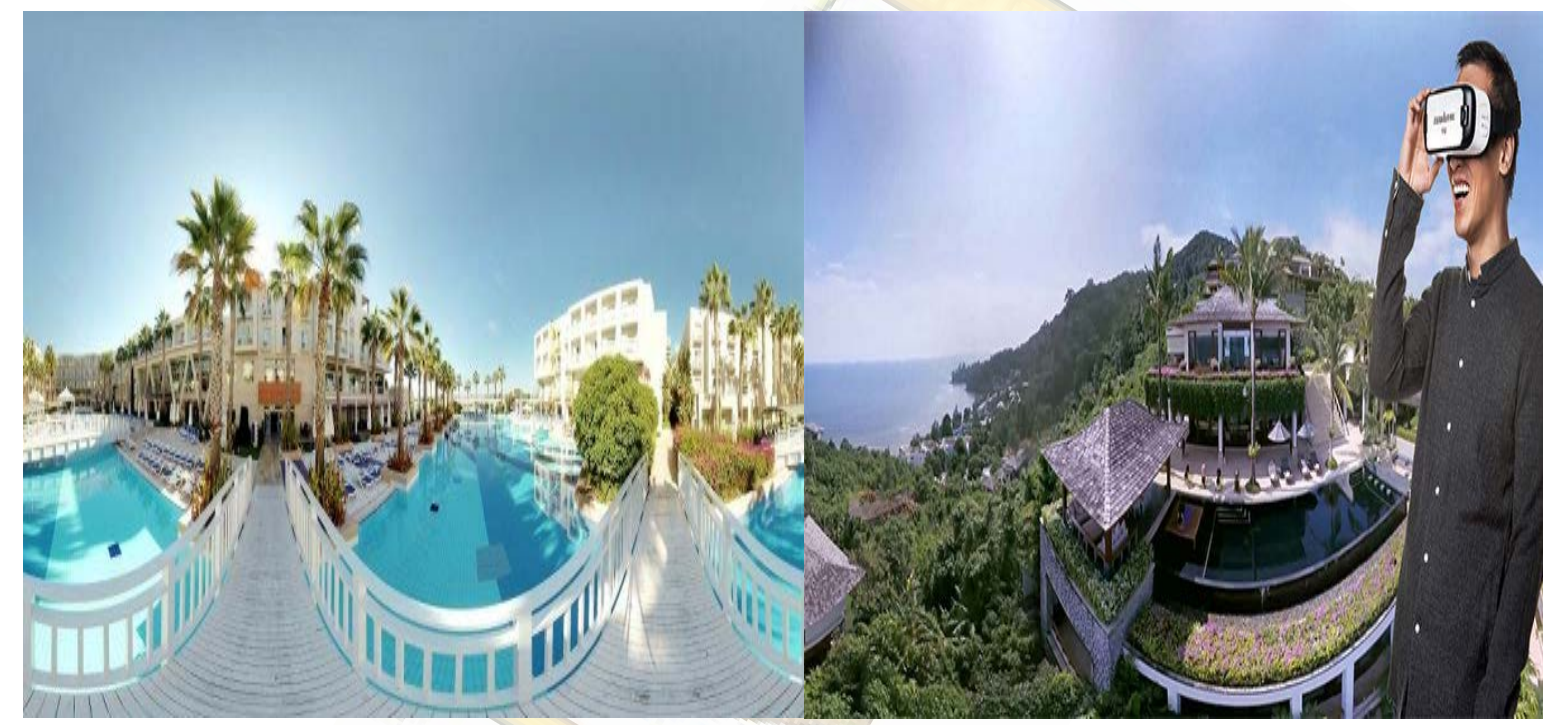

Figure 3. 360 Degree Virtual Hotel and Environment Tour

Source: Yaral Mercan, 2018.

Although it is possible for hotel businesses to be discovered by potential customers through 360-degree virtual tours before the visit, VR technology can be used for different experiences during the stay in the hotel business. For example, in the "VRoom Service" project, which is realized in cooperation with Marriott Hotels and Samsung, customers can visit China, Rwanda or Chile with virtual reality from where they sit in their rooms. With VRroom Service, guests staying at Marriott Hotels can order a different product than food and beverage with room service: VR Postcards. For this new experience, Marriott Hotels worked with Framestore to create postcards with VR. 360-degree, three-dimensional shooting techniques were used in postcards to create fun and interactive experiences (Durmaz, Bulut and Tankuş, 2018: 37). Therefore, it is possible to state that VR technology is used in the hotel businesses for 
the detailed promotion and advertisement of the hotel's surroundings and in-hotel service units, however, it is also used to offer different experiences such as destination tour to the customers during the stay.

It is possible to state the advantages of VR technologies for hotel businesses as follows (Kuttaş, 2020):

* Attract more visitors and increase reservations by giving access to VR videos on the hotel website,

* Promoting the services offered in hotel businesses to target customers with VR videos and increasing the transparency of the business,

With VR videos, potential customers will have the opportunity to explore the hotel business, see the services on site and receive information, and have a unique sensory experience,

* Creating VR video with low cost equipment,

To be able to make an effective content marketing using VR.

\subsubsection{Virtual Reservation}

In the travel and tourism industry, potential customers have the opportunity to pre-experience the products and services of tourism businesses in the VR environment, where they did not know before. VR today is an important support tool that accommodation and travel businesses use to attract more customers and maintain direct bookings. Accommodation and travel businesses use virtual tours to promote their touristic product options to potential customers and try to increase their effectiveness in marketing with VR videos. Users who visit websites to make reservations take into account the information supported by 360 degrees VR and make a reservation by making a purchase decision. Supporting tourism companies' websites with virtual tours will increase the number of visitors to the page and the willingness of these potential customers to make reservations. For this purpose, reservation tools supported by virtual reality technology have been created in recent years, and reservations can be made quickly and easily at the end of the virtual tour (SiteMinder, 2020). 


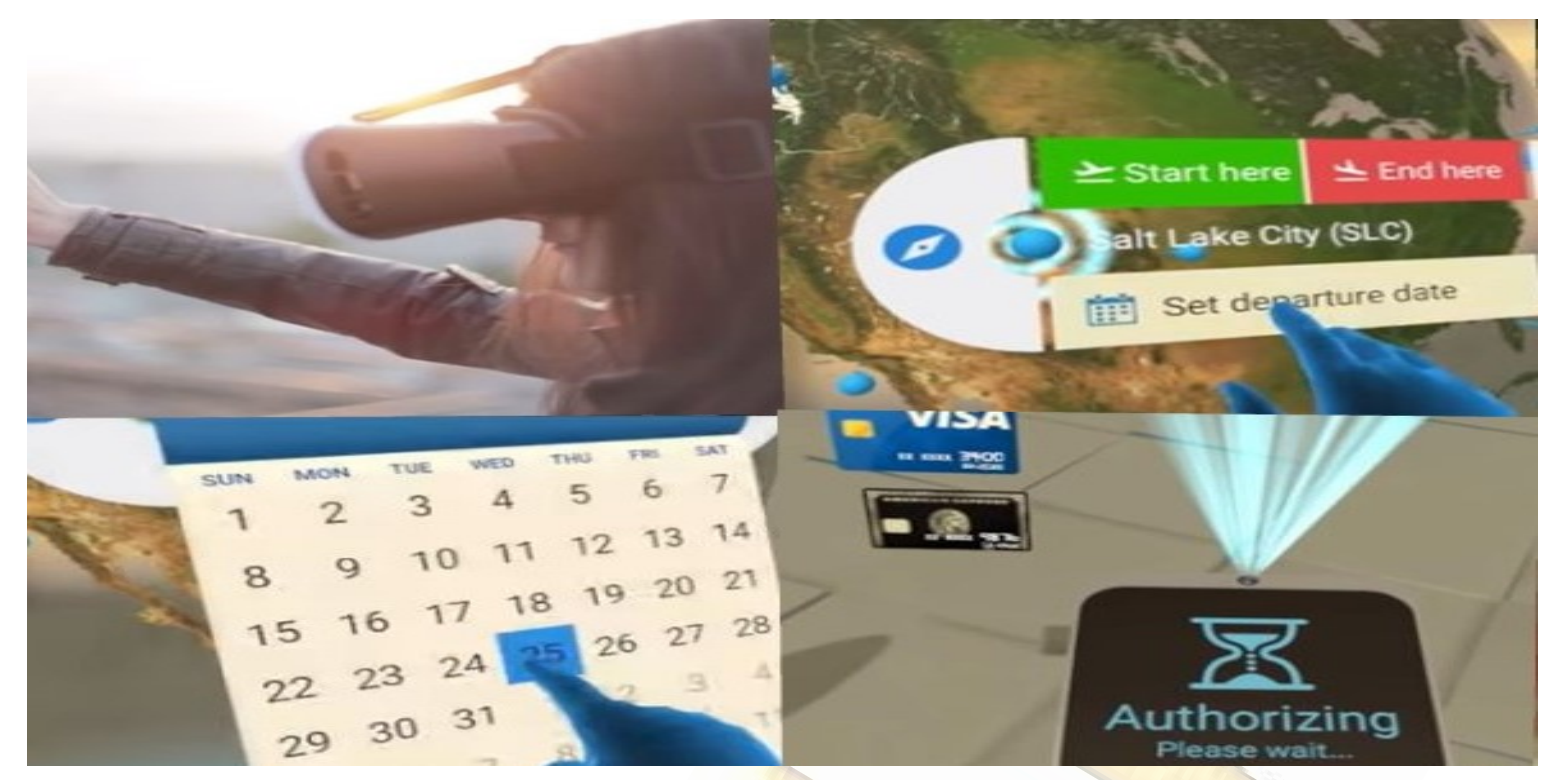

Figure 4. Amadeus VR Destination Search and Reservation Experience

Source: Adopted from Revfine, 2020.

Today, it is seen that some businesses operating in the travel and tourism industry have started to move the entire reservation process into a VR environment by further improving their use of VR. It is envisaged that the need for computer or touch screen devices required to make reservations in digital environment will disappear with the development of VR reservation (Revfine, 2020). Therefore, it is noteworthy that traditional digital reservation has started to change with VR. With a VR application used by Amadeus company, people can create a pre-experience by visiting a business or destination as if it is real and they can make a reservation by choosing the features of the service, date ranges and paying. Reservation transactions made in the online reservation environment are transferred to the VR environment and potential customers make the reservation process by having more pre-experience and knowledge about the touristic services to be purchased.

\subsubsection{Virtual Travel Experiences}

Human-technology interactions in different reality environments can be used by businesses to enhance customer experience. Digital technology elements added to the service offerings of the enterprises can increase customer experiences and technology supported customer experiences occur. Experiences where technology is very limited or in the secondary plan are described as "core experiences". However, 
core experiences, including human-technology interactions, constitute technologysupported experiences in which more valuable customer experiences are formed (Flavian, Ibanez-Sanchez and Orus, 2019: 554). Virtual tours and travel experiences draw attention as the most important innovations emerging with the virtual reality technologies developing in recent years (Farah, Ramadan and Harb, 2019: 556).

The virtual tour is created by transferring three-dimensional images onto the photos as visual media with the latest technology software. Virtual tours allow visitors to easily navigate a place on the web, creating the feeling that they are really visiting here. Visiting a place or destination with a sense of reality offers a new travel experience. The developments in virtual tour technologies in recent years allow countries and tourism businesses to reach three-dimensional destinations based on panoramic images (Durmaz, Bulut and Tankuş, 2018: 39). Thus, virtual travel experiences are created and historical places, businesses, event areas, museums, etc. are created and can be visited in a virtual environment. Within the scope of VR technology, trends and innovations in the field of virtual travel can be summarized as follows (ImmersionVR, 2020):

$\checkmark$ VR travel experiences offered by travel companies,

$\checkmark$ New technologies that will make VR travels more realistic,

$\checkmark$ VR travel experiences for the elderly people,

$\checkmark$ VR flight experiences,

$\checkmark$ VR in destinations in remote areas of the world.

Virtual travel experiences can be an effective factor for potential visitors to make a purchase decision together with the functions of seeing previously unseen destinations in a VR environment and creating pre-travel experience. A detailed tour of places and destinations with virtual travels contributes to people who do not have a chance to visit a place, to experience tourism by visiting that place in a virtual environment. As the development and adaptation of these technologies take place, the importance of VR technologies that increase customer experiences in the travel and tourism industry will increase more. 


\subsection{Benefits of VR in Travel and Tourism Industry}

VR technology draws attention as one of the technological innovations used by businesses in the field of travel and tourism in recent years, from accommodation services to travel experiences. 360-degree tours provided by VR allow tourism establishments to be visited, discovered and prior experience to be realized before purchasing. For example, the general usage areas such as the lobby, activity center, pools, restaurants inside the accommodation establishments and the exterior of the hotel can be examined in detail with VR videos. With this technology, different experiences can be offered to potential customers by introducing more detailed and effective tourism businesses.

Visits of places that cannot actually be visited can also be made possible by using VR technology. For example, a virtual model of the Canadian Rocky Mountains was created on the computer, making it possible for two people to experience such an experience without changing the location at the same time. As another example, 'The Abbey of Cluncy', which was destroyed in the Burgundy region of France after the French Revolution, was rebuilt in computer environment with the help of VR from archive records. With VR technology, this structure was provided to be visited in the virtual environment to the finest details (Bayraktar and Kaleli, 2007: 6).

Therefore, visiting the places that exist in reality and touristic attractions that do not exist physically is one of the other benefits provided by VR. It is possible to summarize the benefits of VR in the travel and tourism industry as follows (ImmersionVR, 2020):

- Allowing the user to imagine themselves at a travel destination

- Being able to showcase 360 degrees of a destination in high resolution

- Enabling the user to explore a scene at their own will

- Creating memorable and unique experiences for the user

- Creating unique brand engagement

- Allowing travel companies to stand out from the crowd

- Providing travel experiences to those that cannot travel

- Reducing impact of tourism on vulnerable destinations 


\section{AR TECHNOLOGY IN THE TRAVEL AND TOURISM INDUSTRY}

Along with the rapid developments in technology, visualization and simulation possibilities increase and develop. AR stands out as one of the best examples of visualization methods that add a new dimension to the interaction between digital devices and the real world. AR technology, which creates virtual experiences by increasing the interaction between the real world and the digital world, integrates digital information into the physical world through cameras. People can access digital information through AR technology, and this technology offers an important innovation in disseminating information. The use of this technology by businesses changes traditional methods of accessing information in the travel and tourism industry (Ramos et al., 2018: 1-2).

\subsection{AR Concept}

AR can be defined as "adding virtual objects to real images through internet access and smart devices (computer, smart glasses, smart gloves, etc.)". In this technology, data such as audio, video, graphics are produced by some smart devices and a new perceptual environment is created by combining sensory/perceptual input with the real environment (Demirezen, 2019: 4). In other words, AR basically involves increasing users' perceptions and areas in the virtual environment, obtaining additional information about objects in the physical world and combining the visual perspectives of users with digital content. AR enables a person's brain to perceive virtual elements and images that do not actually exist. The elements that are added digitally and that can be viewed simultaneously in the physical environment are digital content that does not actually exist, added to the image of objects. It is a representation of objects that can be seen in the physical environment in threedimensional holograms (Olney, 2019: 2).

AR, shown among the most popular applications of the 21st century, is a technology created by integrating virtual objects onto real images using the object identification feature of the devices. In order to benefit from AR, internet access and devices (smart glasses, smartphone or tablet) that will define the AR must be available in the environment. However, one of the applications that enables the use of AR 
technology must also be installed on these devices. After these technical conditions are met, objects are identified by the application in devices designed for AR, the device detects the object and a new image is obtained. There are AR products produced by various companies for the use of this technology (Aşkan, 2018). Achieving the best results in combining the virtual world with real images is seen as the main target in producing AR products. In this technology, virtual objects integrate real images with complementary images, and three-dimensional complementary images are obtained from different viewing angles. When users see the objects that interest them and want to learn more, it is enough for them to touch the cursor they see on the object. The options in the menu that provide information about what can be done when they touch the cursor are shown. This information is provided in a multimedia environment that includes two-dimensional images (maps, old photographs), short films, threedimensional models of existing or nonexistent objects (Fritz, Susperregui and Linaza, 2005: 5).

AR is the merging of the real world and the virtual world with the information shown in the virtual environment to provide additional information about something in the real world. For example, a person can look at a real painting or machine, by holding her/his smartphone or tablet towards the painting or machine, she/he can obtain additional information she/he wants to learn about them in a virtual image. Information about the painting can include additional information about the person who made the painting, the painting technique she/he used and the life of the person who made it. However, additional information such as activation, operation, parts of the machine can be obtained in AR. New technical features such as computer image, object identification, global positioning system (GPS) are available in AR technology. The display technologies required to deliver AR experience are also developed today. For example, marker-based AR technologies operate on the basis of defining a certain content or information, image and perception by the user (Nayyar et al., 2018: 156-158). It is noteworthy that the use of AR technology has become widespread in recent years with the rapid developments in technology. AR technology is used for various purposes in many fields from service industry to production industry. Marketing, 
cinema, education, logistics, arts and museums, games, construction, tourism are seen as major areas using AR technology (Aşkan, 2018; Nayyar et al., 2018).

\subsection{AR Usage Areas in Travel and Tourism Industry}

While it is seen that filtering applications on social media platforms such as Facebook, Instagram, Snapchat are becoming very popular nowadays, many AR applications can be used via smart phones. There are many AR applications in application stores such as Android and IOS, and businesses and brands that offer the opportunity to use this application aim to increase their customer experience. While the stores selling furniture and home products are among the most widely used examples of AR, consumers can find the opportunity to try and see the products they are interested in using AR. These advances in AR technology create new opportunities in product and service offerings for businesses (Interactive Advertising Bureau, 2019: 18-20). In the travel and tourism industry, it is seen that AR technology has started to be used in various ways today.

\subsubsection{Tour Guiding}

Tour guiding is an informative and guiding profession in the visits of touristic areas and destinations with a historical, cultural past that have not been visited and seen for the first time. Its guiding and informative functions make tourist guidance an important position for visitors in the tourism industry. In addition to professional tourist guides, it is seen that the use of assistive technologies has increased in the travels of people today. With the widespread internet access and smartphone use, people can organize their own travels and access instant information about the places visited. There are many mobile applications developed for this and the use of mobile tour guides is becoming widespread among people today. It is noteworthy that AR applications in recent years have served as a tour guide in the field of travel and tourism, as well as online travel maps, navigation applications, social networking sites (Seo, Kim and Park, 2011: 276).

It is seen that the AR technology, which is based on providing additional information about real-world objects in the virtual environment, has been used for various purposes in the tourism industry in recent years. AR technology allows 
planning the travels, creating pre-experience and accessing necessary information with simple and interactive methods. Offering a different experience for tourists, this technology can function as a tour guide with directions around the destination before and during travel, translation into a foreign language, audio signs and dialogs. All this can be done with a mobile device such as a smartphone or tablet (Nayyar et al., 2018: 156). AR technology guides its users to interact with virtual content instantly, thus allowing them to experience different methods for searching, navigating or discovering the real world. Conventional navigation applications provide a simple, utilitarian experience based on a single target. This enables people to go from point A to point B. However, creating a list of previously searched places on the application, showing them automatically in searches, giving information, combining them like a travel guide and creating a travel experience in this way can be done with AR. Therefore, the AR can increase a traditional utilitarian experience with richer content (Mathew, 2018).

Visual tracking systems located at various points of destinations enable visitors to obtain information with computer aided three-dimensional virtual visuals using AR technology. Content information about tourist visiting points and their features are provided with AR technology and this technology functions as a personalized tour guide. AR created by adding virtual information to real-world images offers different solutions for on-site tour guidance service. Unlike traditional tour guide applications, AR-based tour guides allow tourists to have innovative and realistic experiences with virtual contents offered at destinations (Seo, Kim and Park, 2011: 276).

\subsubsection{Hotel Businesses}

The first thing people think about when planning a holiday is the accommodation. Hotel businesses, which have an important place in accommodation establishments, are trying to use technology effectively in their service offerings. The AR technology, which has been developing and becoming widespread in recent years, is an important tool in promoting the opportunities offered by hotel businesses in a virtual environment and informing potential visitors. Hotel businesses have AR application that can be used when scanned by a compatible device in guest rooms, 
activity and general use areas. With this application, virtual information is provided about different points and service units of the hotel business, and this virtual experience can be turned into real experiences (Smacar, 2018). AR is becoming more and more widespread in the accommodation area, as it offers hotel businesses the opportunity to promote the physical environment they market more effectively and to increase the experience of exploring the business and its surroundings. However, the increase in the amount of information requested by visitors before arriving at the hotel business and during accommodation increases the importance of the AR in hotel businesses (Revfine, 2020).

One of the most important goals of hotel businesses is to offer its guests advanced and updated facilities that turn their accommodation into unforgettable experiences. AR is the assistive technology that enables guests to have new experiences in their accommodation in line with this goal. Guests who use AR technology with smart glasses, as well as tools such as smart phones and tablets, can have a different experience in areas such as hotel rooms, lobby, restaurant by combining digital contents with objects. AR is used with the addition of digital information to areas such as refrigerator, television with bathroom, window etc. in hotel rooms. In addition, this technology can be used to introduce the activities in the hotel businesses to the guests by the employees. AR is a technology that can also be used to provide guidance services to guests within the hotel (William, 2019).

Some of the most effective uses of AR technology in hospitality businesses are as follows (Revfine, 2020):

- Interactive Hotel Rooms: It is noteworthy that hotel managers use AR to improve their service offerings and include interactive features in hotel rooms. For example, at The Hub Hotel in England, there are wall maps used with AR technology on the walls of the hotel rooms. Guests holding their smartphones towards this wall can access additional information about places of interest.

- Gamification: Hotel businesses are now using AR games to enhance their total accommodation experience. Hotel businesses make their location an important part of the current AR games, develop their own game applications, so the 
discovery of the hotel and its surroundings becomes more interesting and fun for guests.

- Augmented Hotel Environment: Many hotels enjoy the benefits of AR to make the business environment more attractive and enjoyable. For example, the Holiday Inn hotel has created an AR hotel experience that allows its guests to see realistic virtual images of famous people at various points using their smartphones. There are also AR applications for children within the hotel businesses. For example, Best Western Hotel uses augmented reality technology to make children see themselves among Disneyland characters.

- Beacon Technology: It is another technology associated with AR technology. This technology, which works with Bluetooth, allows marketers to send information messages to customers when they arrive at certain locations. It is seen that this technology, which is valuable for hotel owners and managers, is used effectively. For example, Starwood Hotels uses this technology to send virtual room keys to their guests, allowing them to open their room doors using their phones. It is noteworthy that other hotel businesses use beacon technology at certain times to send maps and other information.

\subsubsection{Food and Beverage Experiences}

It is seen that in the food and beverage businesses, which have an important place in the tourism industry, the methods of providing services have also changed with the developing technology in recent years. AR technology, which can be used via smartphones and other devices, creates different service experiences with various applications in food and beverage businesses. In the menus used in restaurants, more information about food and drinks can be provided with AR technology and a more interactive presentation can be made. In addition, AR can be used in food and beverage businesses for more personalized service delivery (İlhan and Çeltek, 2016: 591). With AR technology, restaurants are able to offer their customers more detailed, interactive information about their services, location information, types of cuisine and their own special flavors. The restaurant logo or markers on the products are scanned and information is provided with three-dimensional product images. Restaurants can attract customers by presenting 360-degree images of their businesses, and can show 
photos of the dishes they serve using the Google Images application. However, the content, portion sizes and prices of dishes can be presented with AR with threedimensional virtual models (Smacar, 2018).

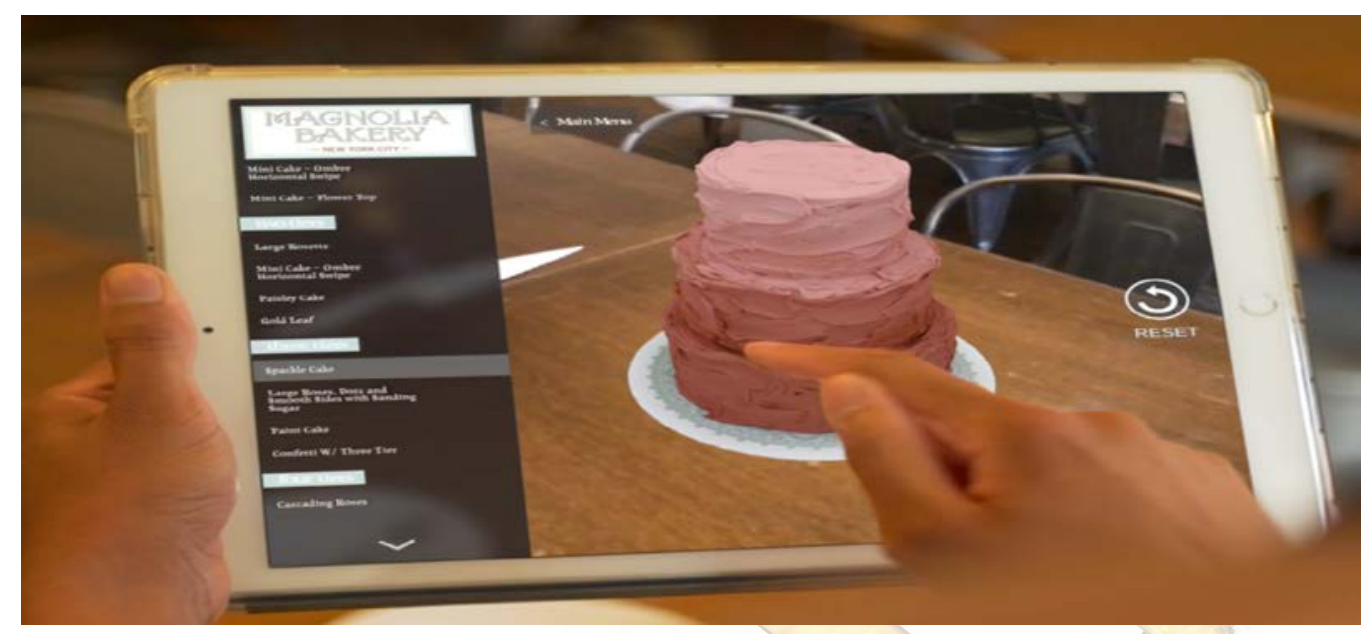

Figure 5. AR Product Presentation

Source: QReal, 2020.

Restaurant businesses effectively use AR technology in product presentation, visuals, information and other services. For example, the KABAQ application developed by the QReal company for restaurant businesses allows its users to view food in three dimensions in virtual environments in restaurant or online food orders. Serving with the slogan "Augmented Reality Food”, Kabaq application uses advanced scanning technologies to create three-dimensional models with ultra high resolution, these models are also used for VR and MR experiences. With the Kabaq application, which can also be used by catering companies and event organizers, customers are given the chance to make their menu selections under more favorable conditions in the virtual environment. The food choices of customers are under their control, and with AR, they can see food and drinks as if they are real at their tables. Thanks to this technology, customer expectations can be met better and satisfaction can be increased (Kabaq, 2020).

\subsubsection{Museums and Historical Sites}

Museums use every method to interact with their customers and increase this. Museums, which try to attract potential visitors as well as their current visitors, are trying to increase the number of young visitors, especially these days. By using AR 
technology in museums, art galleries, historical sites and ruins, the attraction of these places for the visitors is tried to be increased. By using AR with a smartphone, tablet or smart glasses, it is possible to visit museums and historical sites, to get information about the artifacts, historical places and ruins. Users can recreate the paintings exhibited using AR or repaint these, etc. applications can also be realized (İlhan and Çeltek, 2016: 588).

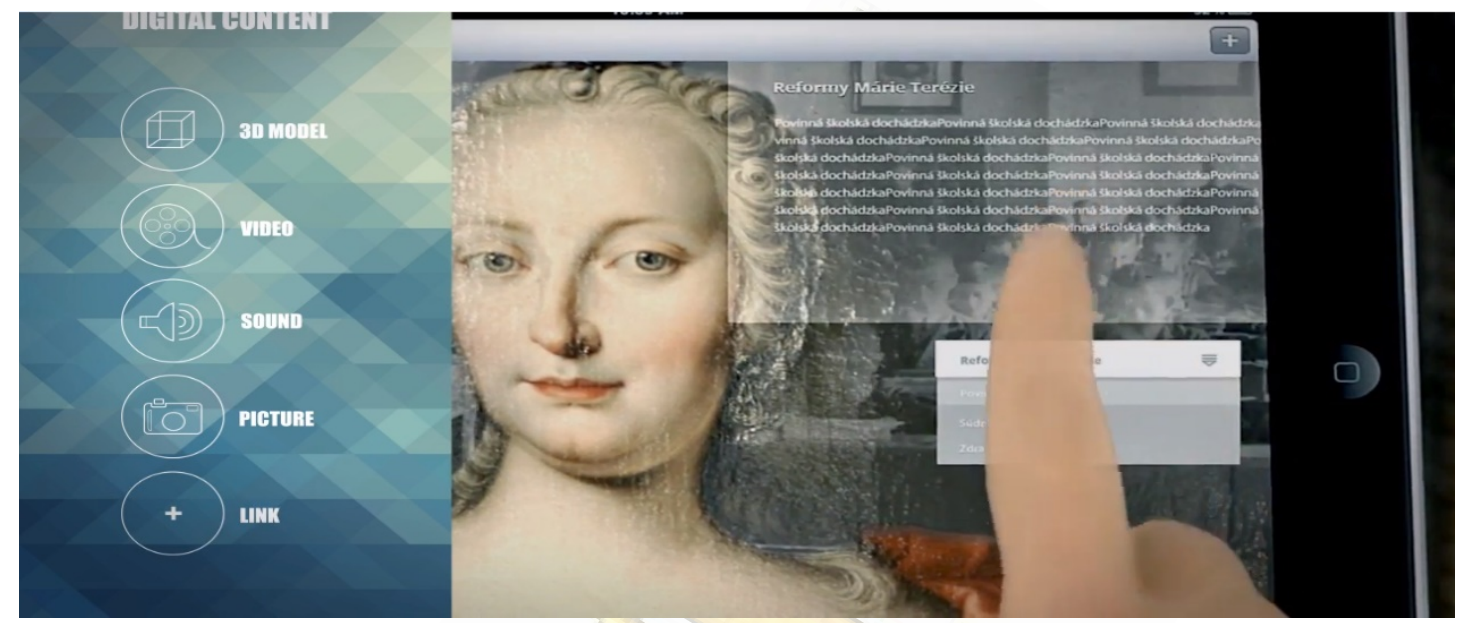

Figure 6. AR Use in Museums

Source: Strategic Slovakia, 2016.

The AR technology, which allows historical places such as monuments and battlefields to be seen by visitors with a three-dimensional sense of reality, helps to create a clear picture of how these places looked in previous periods. Along with providing detailed information about these places, AR can also show the formation of continents over time. Virtual information integrated into physical objects can make museum visits more interesting. Visitors can have different experiences with the feeling of reality by using AR technology while visiting historical places, museums, ruins, and obtain more detailed information supported by visuals (Smacar, 2018).

\subsection{The Importance of AR for the Travel and Tourism Industry}

AR stands out as a technology used by various businesses operating in many fields from production to service in recent years. In tourism, which is one of the industries affected by technological developments, AR can be used for different purposes, from marketing products and services to differentiating experience. AR technology, which is described as an innovative approach in product and service 
offerings, is an important tool in the reservation stage, holiday purchase decisions, from the beginning to the end of travel experiences. In recent years, it is seen that researches in the field of tourism have focused on the interaction of people with technology in their holiday experiences and different uses of AR are investigated. In addition, AR technology is an important assistant when visitors are visiting destinations, visiting museums and learning about historical sites (Gaberli, 2019: 6466).

Increasing the visuality, discovering, restructuring and interacting are among the main uses of AR in the travel and tourism industry. In addition to the visual objects presented in museums, it is possible to discover the reality of the background of these contents and to learn different aspects of it with AR. However, by using augmented reality technology, interaction can be provided in virtual environment with the help of three-dimensional visuals and some works and places can be reconstructed by the user. This provides a different experience for the visitors. The possibilities provided by this technology can allow the display of cultural heritage sites that do not physically exist and/or that cannot be visited in reality (Bekele et al., 2018: 1).

It is noteworthy that AR has important functions in the field of tour guidance with accommodation and food businesses. AR can offer important advantages to tourism businesses in the presentation, visualization and information of products and services before and during accommodation. Accommodation turns into a more unique experience, dining experiences and service provided become more satisfying. Supporting the menus used in restaurants with AR allows customers to have more detailed product information and fulfill their orders in a complete and appropriate manner. In addition, the fact that the hotel rooms have more visual equipment with AR technology enriches the guest experiences and enables service differentiation. Therefore, the use of AR technologies in the travel and tourism industry can increase the perception of the quality of the services provided, thereby ensuring customer satisfaction. 


\section{MR TECHNOLOGY IN TRAVEL AND TOURISM INDUSTRY}

The relationship between AR and VR technologies and the new technology created by using them together are described as MR (Clark, 2019: 19). MR enables people to see and interact with each other by coming together in the same artificial virtual environment regardless of their geographical location. However, this technology creates the feeling that the person is surrounded by in-depth reality with head, hand, eye tracking, sense of touch and 360-degree visuality. Therefore, it increases virtual experience by combining VR and AR applications (Volkow and Howland, 2018: 29). Today, most businesses operating in the hospitality and service industry use MR applications to increase the sense of high reality and interaction. In line with these developments, applications developed for MR in the travel and tourism industry have also increased in recent years (Hammady et al., 2020: 3465).

\subsection{MR Concept}

MR is seen as a virtual technology experience that is formed by combining VR and AR technologies. In this technology, AR users are allowed to have real physical experiences with the help of VR elements such as pictures, videos, digital objects. MR expresses the reality of a more advanced virtual environment that is created by the combination of VR and AR technologies (Flavian, Ibanez-Sanchez and Orus, 2019: 549). When the related literature is examined (Clark, 2019; Fast-Berglund, Gong, and Li, 2018; Storchi, 2018), it is noteworthy that the concept of extended reality can be used instead of MR. It is possible to state MR as a new reality technology created by combining the features of VR and AR technologies. In addition, blended reality, which is expressed as the simultaneous interaction between the real and the virtual world, is also seen as one of the names used instead of MR (Orhan and Karaman, 2011: 377). 
Table 1. Similarities and Differences Between Reality Technologies

\begin{tabular}{|c|c|c|}
\hline VR & AR & MR \\
\hline $\begin{array}{l}\text { Indirect relationship } \\
\text { between users and } \\
\text { reality }\end{array}$ & $\begin{array}{l}\text { Direct relationship between } \\
\text { users and reality }\end{array}$ & $\begin{array}{l}\text { Direct relationship between users, } \\
\text { reality and virtuality is possible }\end{array}$ \\
\hline $\begin{array}{l}\text { No interaction between } \\
\text { reality and virtuality } \\
\text { Interaction between } \\
\text { users and virtuality }\end{array}$ & $\begin{array}{l}\text { No interaction between } \\
\text { reality and virtuality } \\
\text { Interaction between users } \\
\text { and virtuality }\end{array}$ & $\begin{array}{l}\text { Interaction between users, reality and } \\
\text { virtuality is possible }\end{array}$ \\
\hline $\begin{array}{l}\text { Remote collaboration is } \\
\text { possible }\end{array}$ & $\begin{array}{l}\text { Co-located and remote } \\
\text { collaboration }\end{array}$ & Remote collaboration is possible \\
\hline $\begin{array}{l}\text { Co-located collaboration } \\
\text { is irrelevant }\end{array}$ & & Co-located collaboration is irrelevant \\
\hline $\begin{array}{l}\text { High level engagement } \\
\text { due to immersivity and } \\
\text { realism }\end{array}$ & $\begin{array}{l}\text { High level engagement with } \\
\text { virtual environment due to } \\
\text { interactivity }\end{array}$ & $\begin{array}{l}\text { Average engagement due to streaming } \\
\text { 2D images (video) to 3D virtual } \\
\text { environment hinders experience }\end{array}$ \\
\hline
\end{tabular}
Source: Bekele and Champion, 2019: 6.

$\mathrm{MR}$, which is formed by bringing the real and virtual world together in real time in three dimensions, is the application that enables the physical world to be integrated in the same frame. Here, it is important that reality be compatible with the virtual in terms of location and content in order to obtain an understandable and more realistic image. Optical based systems used in MR technology are based on visualizing the image on the retina. Since this is costly, video-based systems, which consist of processing the images one by one with a camera or display device and presenting them to the user, are preferred. MR has different functions such as determining the position of the user with the help of GPS, determining which direction to look with the help of digital compass and accelerometer. By using these features of MR, it is possible to integrate the desired data into the real world. Along with the developments in computer and internet technologies, it is seen that important developments have occurred in this field since the 1990s to the present day. Today, MR is a technology used in fields such as informatics, advertising, marketing and entertainment services (Özarslan, 2011: 727).

MR technology includes 360-degree three-dimensional visuals, interactive technology and real-time movements of people in the virtual environment. With interactions that create a sense of reality, the physical world is combined with the virtual world, and VR and AR is taken one step further. For example, with the MR applications developed for children, interaction with VR applications is provided 
within the physical world. Children physically enter into a completely virtual world and come together in interaction with other children in the same virtual environment. Two-dimensional or in-depth three-dimensional 360-degree interactive visualization provides an experience that surrounds multi-channel sounds with a high sense of reality. In addition, 90 people can interact simultaneously in this MR application developed for children (Bluff and Johnston, 2017: 360). Therefore, people in MR can be heard, felt and interact with surrounding objects in a real environment simulation.

\subsection{Functions of MR Technology}

MR technology is formed by combining virtual image and real-world image by reading an embedded target with the help of camera or display device. MR aims to create environments that complement the points where the applications used to create rich virtual content are weak at a realistic level. MR, which enables the interaction of the physical world and virtual objects, can be used today in the modeling of objects and events in the fields of medicine, engineering, aviation, and architecture. In addition, this technology is used in the visualization and interactive presentation of many museums and historical sites for learning. $M R$, which does not require very high costs in terms of hardware, is a technology that people can use through their current tablet and smartphone (Özarslan, 2011: 728).

MR technology draws attention as a method that is frequently used as an education and teaching technique. In an active environment created by computer simulation, people can come together, meetings, trainings and informations can be realized by taking advantage of MR with the feeling of being in the same environment. MR adds a sense of presence to the VR experience, creating an increasing reality with touch, 360 degree viewing angle, head, hand, and eye tracking. When these features are combined, being in an environment, surrounded by a real and virtual environment takes place (Volkow and Howland, 2018: 29). These features of MR are used to increase users' experience in various business areas. Understanding interesting objects and the environment, establishing a deep relationship with them, creating a sense of reality and experience are among the most important functions of MR technologies (Gochfeld et al., 2018: 362). 
One of the features that mixed reality technology offers to users is the feeling of touch. Touch technology or science is a technology that provides tactile feedback, creating real touch feeling with the help of power, vibration and/or movements on the user. This technology can only be used to help create virtual objects in the simulation environment, to control them and to remotely control machines and devices. MR, created by combining VR and AR technologies, enables users to perceive the sense of touch more with the sense of presence in the virtual environment. Here, MR in the virtual environment symbolizes the sensory, perceptual and visual identical model of physical reality (Handa, Aul and Bajaj, 2012: 1-2). MR technologies, which have started to be used in many areas from education to health, from engineering to entertainment, are now a tool that also changes the shopping experience. MR with the function of merging the physical and virtual world will differentiate the shopping experience by making smart phones more suitable and developed for this technology. The changes expected to occur with MR technology in trade are as follows (Ortiz and McGiffin, 2019: 1-3):

> Creating Pre-Experience for Products: Today, consumers benefit from pictures, videos, product information and user reviews before purchasing products online. MR technology provides the opportunity to examine and experiment with the feeling of reality in the virtual environment where the products are located.

Developing Post-Purchase Relations: After purchasing, businesses can use MR to develop closer relationships with their customers. After-sales support services and customer relations can be carried out more realistic and interactive in a MR environment.

> Increasing In-Store Experience: By using MR and artificial intelligence technology together, these technologies can be used as a supportive tool during the store visits of consumers to see a product.

Symbolizing the Brand with the MR Avatar Application: The MR avatar can be used as a body to stimulate the brand of businesses. For this, an experience strategy that enables the use of artificial intelligence supported MR should be 
developed and implemented. This avatar will be an interactive, live helper for customers.

\subsection{MR Usage Areas in Travel and Tourism}

Due to the structural feature of the travel and tourism industry, it is an area where services that couldn't be tried before are purchased. This uncertainty poses a risk to potential customers. However, the developing technology is an important tool in reducing the perceived risk in the travel and tourism industry. In addition to websites and various social media applications, the MR technologies developed in recent years are an important aid used in the process of purchasing tourism products. By using MR technology, it is possible to see the products and services offered by tourism businesses in a virtual environment and to experience the feeling of reality and pre-experience. Fast-Berqlund, Gong and Li (2018: 37) state that MR is a flexible technology that can be used in most areas. According to the authors, it is a different experience that this technology combines the physical world and the virtual environment to increase interaction and reality. Travel and tourism is the industry area that is shown among the uses of MR (Gaberli, 2019; Hammady et al., 2020).

In the travel and tourism industry, it is seen that MR technology is generally used in the promotion of destinations, touristic products and services, increasing the attractiveness and interest in them and creating pre-experience for potential visitors. Dyne (2018) highlights the importance of MR in creating unique, best experiences for tourists. The author shows among the most prominent features of MR in tourism that visitors can see information about the region at the same time while visiting a place, that this place can be visited with a sense of reality in a virtual environment and that this trip can be done simultaneously with more than one person. For example, it is possible to visit a destination, a touristic area with 360 degree angled threedimensional MR glasses. This technology enables people to have different experiences and enrich their travel and tourism experiences. The application of MR systems in museums enables the simultaneous integration of virtual images and information about the objects exhibited. Current approaches to MR guidance mainly focus on the integration of visitors with specific content. Developments in holographic IR systems 
reveal virtual guides that can replace the traditional human tour guide model. These virtual guides can make narratives and show high-resolution virtual images of places. These are among the major innovations in the area of tourist guidance. Through this interactive narration, gamification and learning technique, the imagination of the users is increased, motivated and their experiences are enriched (Hammady et al., 2020: 3466). Therefore, the use of MR technologies in museums, which are an important attraction element in the travel and tourism industry, can not only enrich the experiences but also have the functions of the human tour guide.

MR technologies make important contributions to tourism in areas such as accommodation, marketing, entertainment, museum, food and beverage, transportation. It is possible to summarize the benefits of MR technology in the travel and tourism industry as follows (Demirezen, 2019: 15-18):

1- It provides sustainable competitive advantage.

2- Improves service quality.

3- It supports sustainability.

4- Increases attractiveness.

5- It provides convenience in accessing information.

6- Creates an image.

7- Contributes to marketing and promotion activities.

8- Contributes to planning and management activities.

9- It provides income increases.

10- It increases accessibility.

11- It provides efficiency in education.

12- It provides convenience and professionalism in work and duties.

13- Increases security.

14- It provides innovation.

15- It provides satisfaction. 
16- Increases sales.

17- Provides brand loyalty.

\section{CONCLUSION AND SUGGESTIONS}

It is possible to define IR technologies, which have become widespread and popular in recent years with technological developments, as various interactive applications that combine physical reality and virtual environment. Today, IR technologies, which have been used in a wide range from education to engineering, from medicine to the service industry, bring product and service presentations to a new environment. IR technologies can be used by moving the physical world to the virtual environment, creating VR through simulations, simultaneously supporting physical objects with virtual information or providing reality that feels tactile. The aim is to be in a virtual environment with the highest level of reality experience and to benefit from it in various ways. Travel and tourism is one of the most important industries where service offerings are realized by using IR technologies (Gaberli, 2019: 62).

There are technologies with different features and functions that enable interaction with the virtual world within the IR, which is a general concept. One of them, VR, is a technology that can be used with a variety of tools such as virtual glasses, tablet, smart phone and enables people to experience 3D images in a virtual environment. It is possible to receive information about objects in the physical world in AR simultaneously with virtual images integrated on them. In MR, VR and AR technologies are combined. In this way, people are provided with a greater sense of reality, interaction and touch in the virtual environment. The use of these technologies allows people to have different experiences. It can be shown among the inferences obtained as a result of this study that these technologies are used in different ways in the travel and tourism industry from promotion to marketing, product and service offerings.

Studies in the related literature (Kim, Lee and Jung, 2018; Dyne, 2018; Farah, Ramadan and Harb, 2019) draw attention to the use of the IR technologies in the travel and tourism industry and their contributions. For this reason, businesses and 
destinations operating in the travel and tourism industry, where intense competition is experienced, should adapt and effectively use these new technologies to gain advantage over their competitors. The innovations brought by reality technologies that encompass both in terms of marketing and service offerings will lead to differentiation of the experiences offered to the visitors, enrichment of their content, and thus the differentiation of tourism and destination from its competitors. This, in turn, will offer businesses significant benefits for increased customer satisfaction and loyalty, combined with unique experiences.

In hotel businesses, potential visitors can obtain information about the products and services offered before coming to the business through virtual tours and can visit the hotel as 3D in a virtual environment. In hotel businesses, information about the hotel can be accessed with augmented reality during accommodation and these technologies can be used in rooms, general areas and restaurants. The AR technology used in the menus in the food and beverage business can provide customers with information about the preparation of the food, its features, the appearance of the dish and the amount of portion. Hotel reservations can be made in virtual reality environment after virtual tours by using virtual reality technology. Visitors can use IR technologies as a guide in museums and historical places, destinations and have different experiences by obtaining detailed information about them. Therefore, it is possible to state that these reality technologies function as an enriching element of holiday experiences in different areas and units in the travel and tourism industry.

In future studies, a more in-depth analysis of the use of IR technologies in the areas of accommodation, transportation, food and beverage, travel management and tourist guidance can be carried out. Addressing this issue in terms of management in tourism businesses will provide new and important contributions to the related literature. In addition, the effects of the use of these technologies in the travel and tourism industry can be investigated by using different data collection techniques such as observation, interview, survey. Examples of the use of the IR technologies in tourism businesses and destinations can be examined in detail and contributed to the theoretical infrastructure in this field. 


\section{REFERENCES}

Aşkan, L. (2018). “Artırılmış Gerçeklik (Augmented Reality) Nedir? Kullanım Alanları Nelerdir?”. http://www.teknolo.com/augmented-reality-nedir-hangi-alanlarda-kullanilabilir/, Accessed: 09 March 2020.

Bayraktar, E. and Kaleli, F. (2007). Sanal Gerçeklik ve Uygulama Alanları. Akademik Bilişim, 31 January2 February, Kütahya, pp. 1-6.

Bekele, M. K. and Champion, E. (2019). A Comparison of Immersive Realities and Interaction Methods: Cultural Learning in Virtual Heritage. Frontiers in Robotics and Al, 6(91), 1-14.

Bekele, M. K., Pierdicca, R., Frontoni, E., Malinverni, E. S. and Gain, J. (2018). A Survey of Augmented, Virtual, and Mixed Reality for Cultural Heritage. ACM Journal on Computing and Cultural Heritage, 11(2), $1-36$.

Bluff, A. and Johnston, A. (2017). Creature:Interactions: A Social Mixed-Reality Playspace. Leonardo, 50(4), 360-367.

Clark, C. M. (2019). Extended Reality in Informal Learning Environments (Ed. Varnum, K. J.). Beyond Reality Augmented, Virtual and Mixed Reality in the Library içinde, ss. 17-30. Chicago: ALA Editions.

Collins, J. (2019). "How Immersive Technology is Taking the Travel + Tourism Industry by Storm". https://streetsense.com/blog/immersive-technology-in-tourism/, Accessed: 05 March 2020.

Demirezen, B. (2019). Artırılmış Gerçeklik ve Sanal Gerçeklik Teknolojisinin Turizm Sektöründe Kullanılabilirliği Üzerine Bir Literatür Taraması. International Journal of Global Tourism Research, 3(1), 126.

Durmaz, C., Bulut, Y. and Tankuş, E. (2018). Sanal Gerçekliğin Turizme Entegrasyonu: Samsun'daki 5 Y1ldizlı Otellerde Uygulama, Turkish Journal Of Marketing, 3(1), 32-49.

Dyne, J. (2018). “Mixed Reality For Tourism”. https://medium.com/@jon_54445/mixed-reality-fortourism-fa8dd030c9fb, Accessed: 16 March 2020.

Farah, M. F., Ramadan, Z. B. and Harb, D. H. (2019). The Examination of Virtual Reality at the Intersection of Consumer Experience, Shopping Journey and Physical Retailing. Journal of Retailing and Consumer Services, 48, 136-143.

Fast-Berglund, A., Gong, L. and Li, D. (2018). Testing and Validating Extended Reality (XR) Technologies in Manufacturing. Procedia Manufacturing, 25, 31-38.

Ferhat, S. (2016). Dijital Dünyanın Gerçekliğ̣i, Gerçek Dünyanın Sanallığı Bir Dijital Medya Ürünü Olarak Sanal Gerçeklik. TRT Akademi, 1(2), 724-746.

Flavian, C., Ibanez-Sanchez, S. and Orus, C. (2019). The Impact of Virtual, Augmented and Mixed Reality Technologies on the Customer Experience. Journal Of Business Research, 100, 547-560. 
Fritz, F., Susperregui, A. and Linaza, M. T. (2005). Enhancing Cultural Tourism experiences with Augmented Reality Technologies. The 6th International Symposium on Virtual Reality, Archaeology and Cultural Heritage VAST, Pisa, İtaly, 8-11 November, pp. 1-6.

Gaberli, Ü. (2019). Tourism in Digital Age: An Explanation for the Impacts of Virtual, Augmented and Mixed Reality Technologies on Tourist Experiences. Journal Of Tourism Intelligence and Smartness, 2(2), 61-69.

Gochfeld, D., Brenner, C., Layng, K., Herscher, S., DeFanti, C., Olko, M., Shinn, D., Riggs, S., FernandezVara, C. and Perlin, K. (2018). Holojam in Wonderland: Immersive Mixed Reality Theater. Leonardo, 51(4), 362-367.

Greengard, S. (2019). Virtual Reality (First Edition). Massachusetts: The MIT Press.

Güzel, H. (2019). “Genişletilmiş Gerçeklik (XR) Teknolojisi”. https://medium.com/technicallibrary/geni\%C5\%9Fletilmi\%C5\%9F-ger\%C3\%A7eklik-teknolojisi-xr-e165b21273dc, Accessed: 05 March 2020.

Hammady, R., Ma, M., Strathern, C. and Mohamad, M. (2020). Design and Development of a Spatial Mixed Reality Touring Guide to the Egyptian Museum. Multimedia Tools and Applications, 79, 3465-3494.

Handa, M., Aul, G. and Bajaj, S. (2012). Immersive Technology - Uses, Challenges And Opportunities. International Journal of Computing \& Business Research, 6(2), 1-11.

ImmersionVR (2020). "VR For Tourism". https://immersionvr.co.uk/about-360vr/vr-for-tourism/, Accessed: 06 March 2020.

InnovateUK (2019). "The Immersive Economy in the UK". https://www.immerseuk.org/wpcontent/uploads/2019/11/The-Immersive-Economy-in-the-UK-Report-2019.pdf, $\quad$ Accessed: 28 February 2020.

Interactive Advertising Bureau (2019). "Augmented Reality for Marketing An Iab Playbook". https://www.iab.com/insights/augmented-reality-for-marketing/, Accessed: 11 March 2020.

İlhan, İ. and Çeltek, E. (2016). Mobile Marketing: Usage of Augmented Reality in Tourism. Gaziantep University Journal Of Social Siences, 15(2), 581-599.

Joseph, T. (2019). "Emerging Technology Trends in Travel and Tourism". https://www.fingent.com/blog/emerging-technology-trends-in-travel-tourism-industry, Accessed: 05 March 2020.

Kabaq (2020). “Augmented Reality Food”. https://www.kabaq.io/, Accessed: 14 March 2020.

Kim, M. J., Lee, C.-K. and Jung, T. (2018). Exploring Consumer Behavior in Virtual Reality Tourism Using an Extended Stimulus-Organism-Response Model. Journal Of Travel Research, 26, 1-55. 
Kuttaş, S. (2020). Oteller İçin Sanal Gerçeklik Pazarlamasının 5 Avantajı. https://www.turizmgunlugu.com/2020/02/01/oteller-sanal-gerceklik-pazarlamasi-vr/, Accessed: 06 March 2020.

Mathew, N. (2018). "The Killer App for AR-Hologram Tour Guides". https://virtualrealitypop.com/the-killer-app-for-ar-hologram-tour-guides-dbf259f68e55, Accessed: 11 March 2020.

Milgram, P., Takemura, H., Utsumi, A. and Kishino, F. (1994). Augmented Reality: A Class of Displays on the Reality-Virtuality Continuum. Telemanipulator and Telepresence Technologies, 2351, 282-292.

Mosieeva, V. Y., Lavrentyeva, A. V., Elokhina, A. K. and Mosieev, V. I. (2019). AR and VR Technologies as a Factor of Developing an Accessible Urban Environment in Tourism: Institutional Limitations and Opportunities. International Journal of Engineering and Advanced Technology, 8(6), 5313-5317.

Nayyar, A., Mahapatra, B., Le, D. and Suseendran, G. (2018). Virtual Reality (VR) \& Augmented Reality (AR) Technologies for Tourism and Hospitality Industry. International Journal Of Engineering $\mathcal{E}$ Technology, 7 (2.21), 156-160.

Olney, A. (2019). Augmented Reality (Ed. Varnum, K. J.). Beyond Reality Augmented, Virtual and Mixed Reality in the Library içinde, pp. 1-16. Chicago: ALA Editions.

Orhan, S. and Karaman, M. K. (2011). Eğitimde Gerçekliğe Yeni Bir Bakış: Harmanlanmış ve Genişletilmiş Gerçeklik. XVI. Türkiye' de İnternet Konferans1, 30 November-02 December, Izmir, pp. 373-384.

Ortiz, A. and McGiffin, M. (2019). "How Extended Reality Will Reshape Commerce". https://www.ibm.com/thought-leadership/institute-business-value/report/extended-realitycommerce\#, Accessed: 16 March 2020.

Özarslan, Y. (2011). Öğrenen İçerik Etkileşiminin Genişletilmiş Gerçeklik İle Zenginleştirilmesi, 5th International Computer \& Instructional Technologies Symposium, 22-24 September, Elazığ, pp. 726-730. Putro, H. T. (2015). Immersive Virtual Reality for Tourism and Creative Industry Development. The 3rd International Conference on Creative Industry, 11-12 August, Bali, Indonesia, pp. 1-6.

QReal (2020). “AR for the Real World”. https://qreal.io/, accessed: 14 March 2020.

Ramos, F., Trilles, S., Torres-Sospedra, J., and Perales, F. J. (2018). New Trends in Using Augmented Reality Apps for Smart City Contexts. International Journal Of Geo-Information, 7, 1-23.

Revfine (2020). "How Virtual Reality is Transforming the Travel Industry". https://www.revfine.com/virtual-reality-travel-industry/, Accessed: 07 March 2020.

Seo, B.-K., Kim, K. and Park, J. L. (2011). Augmented Reality-Based On-Site Tour Guide: A Study in Gyeongbokgung (Ed. Koch, R. ve Huang, F.). in Computer Vision - ACCV 2010 Workshops, pp. 276285. Berlin: Springer. 
SiteMinder (2020). "Virtual Reality: Is This the New Frontier for Hotel Marketing and Booking Strategies?". https://www.siteminder.com/r/technology/hotel-internet-booking-engines/virtualtours-hotel-marketing-booking/, Accessed: 07 March 2020.

Smacar (2018). "Augmented Reality in the Tourism Industry". https://smacar.com/travel-andtourism-day/, Accessed: 08 March 2020.

Storchi, A. (2018). "Extended Realities: Insights from the Next Generation's Technologies". https://www.academia.edu/37848893/Extended_Realities_insights_from_the_next_generations_tech nologies, Accessed: 15 March 2020.

Strategic Slovakia (2016). "Augmented Reality App For Museums". https://www.youtube.com/watch?v=yzSqDYzabkg, Accessed: 15 March 2020.

Turkish Language Association (TDK) Dictionary (2020). Güncel Türkçe Sözlük, https://sozluk.gov.tr/, Accessed: 02 March 2020.

Volkow, S. W. and Howland, A. C. (2018). The Case for Mixed Reality to Improve Performance. Performance Improvement, 57(4), 29-37.

William, J. (2019). "Augmented Reality: A Recent Technology Debut in Hotel Industry". https://www.traveldailynews.com/post/augmented-reality-a-recent-technology-debut-in-hotelindustry, Accessed: 12 March 2020.

Yaral Mercan, T. (2018). "Sanal Gerçeklik (VR) Jolly Tur İle Türk Acente Sektörüne Girdi". https://www.turizmglobal.com/sanal-gerceklik-vr-jolly-tur-tarafindan-acentecilik-sektorune-girdi/, Accessed: 06 March 2020.

Yıldırım, G., Elban, M. and Yıldırım, S. (2018). Analysis of Use of Virtual Reality Technologies in History Education: A Case Study. Asian Journal of Education and Training, 4(2), 62-69. 